\title{
Artikkeli
}

\section{Kuvajournalismi ja eettisen kuluttamisen haaste}

\begin{abstract}
Artikkelissa tarkastelemme Aamulehdessä julkaistuja eettistä kuluttamista representoivia kuvajournalistisia valokuvia. Keskeinen kysymyksemme on: Millaista eettisen kuluttamisen todellisuutta kuvajournalistiset valokuvat rakentavat? Pohdimme myös, millainen kuvajournalismi voisi edesauttaa ihmisten sitoutumista ympäristön kannalta kestävään arkeen. Tutkimuksessa hyödynnämme muun muassa aiempaa kuluttajakäyttäytymisen tutkimusta, jonka pohjalta rakennamme moniulotteisen kuvan eettisestä kuluttamisesta. Analysoimme aineistoa määrälliseen sisällönanalyysiin nojautuvan kehysanalyysin keinoin. Eettinen kuluttaminen on Aamulehdessä kehystetty kapeaksi ilmiöksi, jossa yksittäisen kuluttajan vaikutusmahdollisuudet painottuvat lähinnä ruokaan liittyviin valintoihin. Kuvia hallitsevat iloiset kuluttajat ja ruokaan liittyvät ammattihenkilöt. Lisäksi kuvissa on ruokaa, ruokapakkauksia ja teknologiaa. Kuvien ihmiset esittelevät ratkaisuja tai poseeraavat. Toimintaa on siis rajallisesti ja yhteys ihmisten arkeen ja kokemuksiin jää pinnalliseksi. Lisäksi ratkaisujen ja ongelmien välinen kytkös on usein jutuissa niin kuvallisesti kuin sanallisestikin löyhä, jolloin on lukijan vastuulla hahmottaa, mihin ongelmaan jutussa esiteltyä eettisen kuluttamisen ratkaisua tarjotaan. Aikaisemman tutkimuskirjallisuuden valossa tarkasteltuna Aamulehden kuvasto ei herättele lukijoita eettiseen kuluttajuuteen.
\end{abstract}

AVAINSANAT: eettinen kuluttaminen, kuvajournalismi, ympäristöjournalismi, kehysanalyysi

ässä artikkelissa tarkastelemme sitä, miten kuvajournalismi representoi eettistä kuluttamista. Tutkimuskysymyksemme on: Millaista eettisen kuluttamisen todellisuutta kuvajournalistiset valokuvat rakentavat? Päästäksemme empiirisesti käsiksi ilmiöön, olemme keränneet systemaattisella otannalla aineiston vuoden 2017 Aamulehdistä'. Keskitymme kuvajournalismiin, sillä visualisointi on yksi tapa tuoda eettisen kuluttamisen kysymykset lähelle ihmisten arkisia kulutusvalintoja ja niihin liittyvien mielikuvien muodostumista. Tähän liittyy toinen tutkimustehtävämme. Poh- 
dimme sitä, millainen kuvajournalismi voisi edesauttaa ihmisten sitoutumista ympäristön kannalta kestävään kulutukseen.

Yleensä eettinen kuluttaminen nähdään ratkaisuna kulutusyhteiskunnan ongelmiin, kuten muovijätteen kertymiseen valtameriin tai ilmastonmuutoksen etenemiseen. Laaja kansainvälinen yksimielisyys ilmastonmuutoksen torjunnan välttämättömyydestä (Claudelin ym. 2018; Figueres ym. 2017, 593) pitänee ympäristönsuojelun ja eettisen kulutuksen kysymykset myös tulevaisuudessa vahvasti esillä julkisuudessa. Medialla onkin keskeinen rooli ympäristöön liittyvien merkitysten rakentamisessa ja levittämisessä (Anderson 1997, 1-6; Hannigan 2006, 79).

Ympäristöjärjestöt ovat median välityksellä tehneet meille tutuksi ympäristönsuojeluun liittyvän kuvaston (Macnaghten 2003, 65), joka on kuitenkin teemoiltaan rajoittunut ja usein kliseinen (Ross 1994, 171, sit. Macnaghten 2003, 67). Rossin (emt., 67) mukaan se koostuu tupruttavista savupiipuista, petrokemialliseen liejuun juuttuneista merilinnuista, mahat ylöspäin kelluvista kaloista, liikenneruuhkista ja avohakkuista. Stereotyyppisistä tuhon kuvista kertoo myös tutkiva toimittaja ja tietokirjailija Hanna Nikkanen:

Jäätiköstä lohkeava jäävuori ja syyrialaisen viljapellon tomuiset korret. Bangladeshin uhattu repaleinen rantaviiva ja talojen rappusia huuhtovat aallot Vanuatussa. Laihoja jääkarhuja, aina jääkarhuja. (Nikkanen 2017, 7.)

Luonnon tuhoutumista esittävien kuvien vastapainoksi asettuvat kuvat koskemattomasta vihreästä luonnosta ja avaruudessa kelluvasta sinisestä planeetastamme. Näitä tapaamme esimerkiksi tuotteiden "vihreyttä" korostavassa mainonnassa.

Vaikka tuhon kuvasto kaappaa huomion, saa ihmiset huolestumaan ja herättää syyllisyyden tunteita, tutkimukset ovat osoittaneet, ettei se aktivoi toimintaan. Kuvasto etääntyy ihmisten jokapäiväisestä elämästä. Macnaghtenin (2003, 63-64) mukaan ympäristökeskustelun vakiintuneet ilmaisut, kehystykset ja kieli eivät ylipäätään onnistu vahvistamaan yhteyttä ympäristön ja ihmisten arjen tai kiinnostuksen kohteiden välillä. Tutkiessaan ilmastoriskin visualisointia ja kuvallista kehystämistä Helsingin Sanomissa myös Kangas $(2016,216)$ huomasi, että vain harvoin kansalaiset kytkeytyivät kuvissa ilmastonmuutoksen syihin tai ratkaisuihin. Kyseinen tulos viittaa siihen, että suomalainenkaan journalismi ei rakenna siltaa ilmastonmuutoksen ja ihmisten toiminnan välille. Ympäristöuhkien kohdalla yksi journalismin haasteista liittyy myös kiistämiseen ja torjuntaan. Vaikka inminen saattaa myöntää ilmastonmuutoksen todeksi, hän voi torjua sen tietoisuudestaan, koska se muodostaa liian suuren uhan hänen psyykkiselle tasapainolleen. Kaikkinensa torjunta ja kiistäminen ovat ihmisen mielen perustoimintoja, joilla on monia merkittäviä yhteiskunnallisia ulottuvuuksia (ks. esim. Cohen 2001; Pihkala 2017, 23). Ne ovat omiaan pitämään ihmiset kiinni vanhoissa, tutuissa ja siksi paradoksaalisella tavalla turvallisissa kulutusvalinnoissa.

Millainen kuvajournalismi voisi edesauttaa ihmisten sitoutumista ympäristön kannalta kestäviin arjen valintoihin? Vaikea ongelma palautuu ainakin osittain paljon keskusteltuun kysymykseen mediaesitysten vaikuttavuudesta. Viestinnän tutkimuksen 
historiassa asiaa on analysoitu monesta suunnasta (ks. Pietilä 1997), eikä tämän keskustelun käyminen ole tässä tarkoituksenmukaista. Monet tutkijat jakavat kuitenkin nykyään käsityksen, jonka mukaan on jokseenkin mahdoton sanoa, miten yksittäinen mediaesitys vaikuttaa tai millaisia merkityksiä juuri se kokijansa mielessä herättää. Jokainen mediaesitys asettuu osaksi laajempia merkityskenttiä, yhdistyy muiden merkitysten (esim. Heikkilä ym. 2012, 161) ja myös kokijansa elämänhistorian kanssa. Jokainen esitys on siis lähtökohtaisesti intertekstuaalinen. Tästä vaikeudesta huolimatta, voimme kuitenkin lähteä siitä, että mediajulkisuus ainakin kattaa pöydän, josta ihmiset ammentavat elementtejä käsityksilleen ympäristöstä ja myös siitä, kuinka ekologisia ongelmia voitaisiin ratkaista (Goodman ym. 2016, 677). Nämä elementit nivoutuvat tai ovat nivoutumatta heidän psyykkiseen todellisuuteensa. Kiinnostavaa on, millaisia mediaesityksiä pöydältä löytyy ja mitkä sieltä puuttuvat. Juuri tämän asian hahmottamista keräämämme aineisto palvelee eettisen kuluttamisen osalta.

Vaikka mediarepresentaatioiden vaikutuksia ihmisten mielissä on vaikea arvioida, aikaisempi tutkimus antaa joitain viitteitä siitä, miten mediaesitykset kannattaa rakentaa, jotta ne edesauttavat eettiseen kulutukseen liittyvien viestin perillemenoa. Ainakin kuvaston linkittäminen ihmisten arkisiin kokemuksiin sekä huoleen omasta, perheen ja lähiympäristön hyvinvoinnista (Macnaghtenin 2003), ratkaisun ja ongelman selkeämpi yhdistäminen mediaesityksissä (Lorenzoni ym. 2006, 277; O'Neill \& Nicholson-Cole 2009, 376) sekä vaihtoehtoisen hedonismin esiintuominen (Craig 2016, 128; Soper 2008, 571-572) voivat edesauttaa inmisten sitoutumista vastuullisempaan elämäntapaan. Soper $(2008,580)$ on myös ehdottanut, että tarvitsemme "esteettistä uudelleenjärjestelyä", jonka kautta tavarat, jotka aiemmin nähtiin houkuttelevan hohdokkaina, muuttuvat vähitellen oudoiksi ja rumiksi assosioituessaan kestämättömään resurssien käyttöön, meluun, myrkyllisyyteen tai kierrätyskelvottomaan jätteeseen. Kaikkia edellä mainittuja ehdotuksia yhdistää ympäristöongelmien lähestyminen ihmisten arkisten valintojen eli eettisen kuluttamisen näkökulmasta.

Eettisen kuluttamisen journalistista representoimista ei ole juuri tutkittu. Yhdessä harvoista tutkimuksista Craig $(2016,124)$ käyttää kuluttajien arjen tasolla ympäristöasioita käsittelevästä journalismista nimitystä vihreä elämäntyylijournalismi (green lifestyle journalism). Hän näkee vihreän elämäntyylijournalismin kuuluvan sekä uutisettä ympäristöjournalismin kategorioihin. Yleisesti ottaen elämäntyylijournalismi voidaan kuvata journalismiksi, joka keskittyy yleisöön kuluttajina tarjoten heille, usein viihdyttävällä tavalla, tietoja ja neuvoja arkielämässä käytettävistä tuotteista ja palveluista (Hanusch 2012, 2). Vihreää elämäntyylijournalismia voidaan pitää myös eräänlaisena palvelujournalismina (Craig 2016, 124). Se puhuttelee lukijoitaan niin kansalaisina kuin kuluttajinakin ja pyrkii ratkaisemaan arkielämän ongelmia yhdistämällä yksilöllisiä ja yhteisöllisiä poliittisen reagoimisen tapoja (Eide \& Knight 1999, 527).

Kaikkinensa journalismilla on tärkeä rooli kansalaisten ymmärryksen lisäämisessä siitä, miten he voivat valinnoillaan hidastaa ilmastonmuutosta ja siten rakentaa itselleen ja lapsilleen parempaa tulevaisuutta. Vaikka ympäristöongelmien ratkaisua ei voida jättää pelkästään yksilöllisten kulutuspäätösten varaan, vaan tarvitaan myös niin poliittisia päätöksiä, rajoitteita kuin suurten monikansallisten yritysten vastuun- 
kantoa (Moisander 2007, 408; Lähde 2017; Piispa \& Myllyniemi 2019), niin silti myös yksilöiden toiminnalla on merkitystä. Vastuullisemmat elämän- ja kulutusvalinnat ovat välttämätön osa ympäristöongelmien ratkaisua (Claudelin ym. 2018). Näiden lisäksi tarvitaan myös aktiivista kansalaisuutta, jonka avulla yksilöt yhdessä pystyvät kohdistamaan poliittisen voimansa muutosta vaativiin ongelmakohtiin (Lähde 2017). Tutkijat ovatkin peräänkuuluttaneet aktiivisempaa ja osallistavampaa mediaa ympäristöuutisoinnissa (Howarth 2012, 222). Craigin (2016, 125) mukaan tarvitsemme journalismia, jossa kansalaisten toiminta ymmärretään laajemmin kuin vain kuluttajaboikotteina tai poliittisina protesteina. Myös tietoisesti kansalaisten osallistamiseen ja julkisen keskustelun lisäämiseen pyrkivä kansalaisjournalismi (Ahva 2010, 48) tarjoaa yhden mahdollisuuden kytkeä ympäristöongelmat kiinteämmin ihmisten arkeen. Kansalaisjournalistiset kokeilut jätämme kuitenkin tämän artikkelin pohdintojen ulkopuolelle.

Seuraavaksi käymme läpi eettisen kuluttamisen tutkimuskirjallisuutta ymmärtääksemme paremmin, mistä eettisessä kuluttamisessa on kysymys. Tämä ymmärrys rakentaa perustaa pohdinnoille kuvajournalismin mahdollisuuksista sitouttaa ihmisiä kestäviin arjen valintoihin. Sen avulla voimme myös rakentaa tutkimuksen sisällönanalyysin muuttujat. Teoriaosuuden lopussa käsittelemme lyhyesti myös lehtikuvilla kehystämistä.

\section{Eettinen kuluttaminen}

Eettistä kuluttamista ei ole määritelty yksiselitteisesti. Ilmiöstä käytetään monia eri käsitteitä, joissa eettisyys saatetaan korvata sellaisilla määreillä kuin kestävyys, vastuullisuus tai tiedostavuus. Usein eettinen kuluttaminen kuitenkin määritellään kulutusvalinnoiksi tai ostokäyttäytymiseksi, jossa otetaan huomioon moraaliset näkökohdat (esim. Carrigan ym. 2004, 401). Niitä ovat esimerkiksi tuotannon ja kulutuksen vaikutukset ihmisiin, eläimiin ja ympäristöön. Eettinen kuluttajakäyttäytyminen ei kuitenkaan ole pelkästään eettisten tuotteiden ja palveluiden ostamista, vaan se voi olla myös kierrättämistä, jakamista, lainaamista, epäeettisten tuotteiden ja palveluiden boikotointia ja kulutuksen minimointia (esim. Cherrier \& Murray 2002).

Tämä artikkeli keskittyy erityisesti lehtikuviin, jotka liittyvät ympäristövaikutukset huomioon ottavaan eettiseen kuluttamiseen. Ympäristövaikutukset tiedostavasta kuluttamisesta käytetään yleisesti myös sellaisia käsitteitä kuin ekologinen kuluttaminen tai vihreä kuluttaminen. Olemme kuitenkin tietoisesti päätyneet käyttämään tässä artikkelissa eettisen kuluttamisen käsitettä, sillä niin ilmastonmuutoksen kuin valtamerien muovijätteenkin kontekstissa ympäristövaikutusten huomioiminen on myös yhteiskunnalle, ihmisille ja eläimille aiheutuvien vaikutusten huomioimista. Lisäksi eettisen kuluttamisen käsite viittaa normeihin ja sääntöihin, joiden perusteella ihmiset toimivat ja tekevät valintoja oikean ja väärän väliltä (Heller 1988, 31-33). Valitsemalla eettisen kuluttamisen käsitteen korostamme siis subjektin toimijuutta ja valintoja.

Vaikka tietoisuus eettisestä kuluttamisesta on kasvanut, sen yleistymisen tiellä on monia esteitä (Szmigin ym. 2009). Pyrkimys valita eettisesti voi monimutkaistaa joka- 
päiväistä elämää. Arjen kiireessä ei aina jaksa miettiä, mitä kaupan hyllystä ottaa. Eettisessä kuluttamisessa asettuvat aina jossain määrin vastakkain myös valinnanvapaus ja moraaliset velvoitteet (Cherrier 2006, 515). Toisinaan yksilön ja yhteisön etu ovat ristiriidassa keskenään (Moisander 2007, 404). Usein kuluttaja ikään kuin uhraa omaa etuaan toteuttaessaan eettistä kuluttajuutta, koska eettiset tuotteet voivat olla vaikeammin saatavia tai muita kalliimpia (Pecoraro 2016, 38). Jopa eettisen kuluttamisen vaihtoehdot voivat olla toisilleen vastakkaisia ja siten asettaa kuluttajan vaikean arviointitehtävän äärelle. Esimerkiksi vesivoimala voi vähentää kasvihuonekaasuja, mutta samalla sekoittaa paikallista ekosysteemiä. (Moisander 2007, 406.)

Eettiset kuluttajat muodostavat kirjavan joukon, johon kuuluvien ihmisten sosio-ekonominen asema, arvomaailma, päämäärät ja motiivit eroavat usein toisistaan (Özçaglar-Toulouse ym. 2006, 510; Pecoraro 2016, 25). Ihmiset voivat esimerkiksi valita saman luomutuotteen niin ympäristö- kuin terveyssyistä. He voivat myös tavoitella samoja päämääriä hyvin erilaisilla keinoilla (Moisander 2007, 406). Jonkun keino oman hiilijalanjäljen pienentämiseen voi olla kasvisruokavalioon siirtyminen, toisen taas lentämisen lopettaminen. Eettinen kuluttaminen ei myöskään aina vaikuta johdonmukaiselta. Vastuullistenkin kuluttajien etiikka usein joustaa esim. ostotilanteeseen, hintaan, laatuun tai mielihyvään liittyvien seikkojen johdosta (Szmigin ym. 2009).

\section{Poliittinen osallistuminen ja vaihtoehtoinen hedonismi}

Soperin $(2008,567)$ mukaan niin kulutusyhteiskunnan kannattajat kuin sen kriitikotkin näkevät, että kulutusvalinnat ovat myös poliittisia valintoja, koska ne vaikuttavat koko yhteiskuntaan. Monet myös ymmärtävät kulutusmyönteisten elämäntyylien myötävaikuttaneen merkittävästi nykyiseen ympäristökriisiin. Tämä on muuttanut ymmärrystämme kuluttamisesta. Eettinen kuluttajuus voidaan nähdä kuluttajan kokemana vastuuna ja pyrkimyksenä vastata globaaleihin haasteisiin, omalla panoksellaan, arkisissa kulutuspäätöksissään (Conolly \& Prothero 2008, 140-141).

Tutkijat ymmärtävät usein yhteiskunnalliset liikkeet organisoiduksi, muutosorientoituneeksi, ulospäin suuntautuneeksi, kollektiiviseksi poliittiseksi toiminnaksi, kun taas elämäntyylejä pidetään itsekeskeisinä, henkilökohtaisen ilmaisun individualistisina projekteina (Haenfler ym. 2012, 1). Haenfler ym. (emt., 2) ehdottavat yhteiskunnallisten liikkeiden ja elämäntyylien väliseen tilaan käsitettä elämäntyyliliikkeet (lifestyle movements). Käsite viittaa liikkeisiin, joille pääasiallinen keino yhteiskunnallisen muutoksen ajamiseen on tietoinen ja aktiivinen elämäntyylin tai elämäntavan edistäminen. Elämäntyyliliikkeessä liikkeen arvot yhdistetään yksilöllisiin ja yksityisiin arkipäivän toimiin, kuten kuluttamiseen, vapaa-ajan aktiviteetteihin, syömiseen ja ruoanlaittoon, pukeutumiseen, rahan hallintaan, matkustamiseen sekä veden ja energian käyttöön. Toimiessaan yksilöllisesti ihmiset kuitenkin ymmärtävät toimintansa vaikuttavan myös oman elämänsä ulkopuolella ja uskovat sekä yksilöllisen toiminnan että koordinoimattoman yhteistoiminnan voimaan. Kun monien yhteiskunnallisten liikkeiden kohteina ovat valtio tai muut yhteiskunnalliset toimijat, niin elämäntyyliliikkei- 
den kohteena ovat kulttuuriset ja taloudelliset toimintatavat. (Haenfler ym. 2012, 6-7.) Esimerkiksi antikuluttamisen päämääränä voidaan pitää vallitsevan kulutuskulttuurin voimien vastustamista (Penaloza \& Price 1993, 123). Kollektiivinen poliittinen toiminta on usein jaksottaista (esim. vaalien rytmittämää), kun taas elämäntyyliliikkeet rohkaisevat ihmisiä integroimaan liikkeen arvot kokonaisvaltaiseen elämäntapaan, jolloin toiminta on jatkuvaa (Haenfler ym. 2012, 7).

Kulttuurisen kulutustutkimuksen piirissä eettistä kuluttamista on usein lähestytty identiteetin näkökulmasta (Pecoraro 2016, 40). Eettinen kuluttaminen voidaan nähdä identiteetin rakentamisen keinona, jonka kautta kuluttaja pystyy ilmaisemaan, millainen hän on (Cherrier 2009, 188; Conolly \& Prothero 2003, 286). Yksilöllisen ja kollektiivisen identiteetin välinen suhde on merkittävä elämäntyyliliikkeissä, sillä vaikkei kaikilla elämäntyyliliikkeillä olisikaan voimakasta kollektiivista identiteettiä (voi jopa olla, että liikkeellä ei ole yhtä yhteistä nimeä), liikkeen piirissä toimivat kuitenkin osallistuvat kuvitteelliseen yhteisöön, joka muodostuu niistä ihmisistä, joiden he kuulevat tai näkevät toimivan samoin kuin he itse toimivat (Haenfler ym. 2012, 8). Näyttämällä miten muut ihmiset toimivat, myös journalismi voi edesauttaa kollektiivisen identiteetin rakentumista ja siten tukea eettiseen kuluttamiseen liittyviä elämäntyyliliikkeitä.

Elämäntyyliliikkeillä ei yleensä ole virallisia johtajia, vaan liikkeen auktoriteetteina voivat toimia niin sanotut kulttuuriset yrittäjät eli yksilöt, jotka esimerkiksi kirjoittavat suosittuja kirjoja, pitävät blogeja tai tekevät dokumentteja aiheesta (Haenfler ym. 2012, 10-11). Nämä kulttuuriset yrittäjät usein korostavat omaa kokemustaan siitä, kuinka heidän valitsemansa elämäntyyli parantaa elämän laatua ja tuo onnea. Esimerkiksi minimalisteiksi itseään kutsuvien Joshua Fields Milburnin ja Ryan Nicodemuksen (2014) ydinsanoma on, että liiallisesta tavarasta ja kuluttamisesta luopuminen ei ole vain luopumista, vaan luopumalla saa enemmän - enemmän aikaa, enemmän iloa, enemmän onnea. Tätä eritavoin kuluttamisen nautinnon -näkökulmaa on vaikeampi löytää journalismista. Craig $(2016,125)$ onkin sitä mieltä, että vihreän elämäntavan käytäntöjen ja niistä raportoinnin pitäisi perustua niin ymmärrykseen elämäntyylien politisoitumisesta kuin myös arkipäiväisen mielihyvän korostamiseen. Hänen tutkimansa brittimedian journalistisessa sisällössä kestävään elämäntapaan liittyvät nautinnot ovat tällä hetkellä vain marginaalisessa asemassa. Eettinen kuluttaja puolestaan esitetään hänen mukaansa usein tiedollisesti puutteellisena, arkipäiväisen toimintansa ympäristövaikutuksista huolestuneena tai ahdistuneena kyvyttömyydestään toteuttaa kestävää elämäntyyliä.

Lupaus nautinnosta on jatkuvasti läsnä medioituneessa kulttuurissamme. Samalla nautinto tuntuu vaativan yhä enemmän ponnisteluja kiihkeässä, työkeskeisessä ja taloudellisesti epävarmassa todellisuudessamme. Eettisen kuluttamisen taustalla ajatellaan usein olevan moraali ja hyveet, jotka liittyvät nimenomaan kulutuksen tuottamasta nautinnosta kieltäytymiseen. (Craig 2016, 128.) Soper (2008, 571-572) onkin ehdottanut vaihtoehtoisen hedonismin käsitettä hyvän elämän uudelleen ajatteluun. Kestävä resurssien käyttö ja ympäristön riistämisen lopettaminen ovat hänen mukaansa riippuvaisia siitä, hyväksymmekö uudenlaisen tavan ajatella nautintoa ja itsensä toteuttamista. Antikuluttamisen etiikan ja politiikan ei pitäisikään siis vedota 
vain altruistiseen myötätuntoon ja ympäristöön liittyviin huoliin. Päätös toimia ympäristöystävällisesti, esimerkiksi kävellä tai pyöräillä autoilun sijaan, ei synny pelkästään ympäristöpoliittisista vaatimuksista vaan myös eri tavalla kuluttamisen nautinnosta. (Emt., 571-572.) Myöskään käsitys eettisestä kuluttamisesta identiteetin rakentamisen ja ilmaisun välineenä (Cherrier 2009, 188; Conolly \& Prothero 2003, 286) ei tue ajatusta, jonka mukaan eettinen kuluttaminen olisi ainoastaan kieltäytymistä tai jonkinlaista altruistista hyväntekeväisyyttä (Soper 2008, 571; ks. myös Pecoraro 2016, 40). Mielihyvän korostaminen eettisessä kuluttamisessa voi myös madaltaa kynnystä kohdata edellä mainittuja ympäristöuhkiin liittyviä ahdistavia, torjuntaan ja kiistämiseen kutsuvia tunnetiloja. Tällöin ihmisen ei tarvitse kokea, että häneltä vaadittaisiin kohtuuttoman suuria uhrauksia ilmastonmuutoksen torjumiseksi.

\section{Kehystäminen ja lehtikuvat}

Eettistä kuluttamista kuvaavien journalististen valokuvien merkityksiä on mielekästä tarkastella kehyksen ja kehystämisen näkökulmasta. Kehysteorian mukaan kuvavalinnat osaltaan vaikuttavat siihen millaisia merkityksiä tai kehyksiä, eli toisin sanoen millaista todellisuutta jutuilla rakennetaan. Mediatutkimuksessa runsaasti käytetty kehyksen käsite on peräisin Erving Goffmanilta (1986, ks. myös Kangas 2016, 212; Karvonen 2000, 79). Goffmanin (1986, 8-11) määritelmän mukaan kehykset ovat kokemuksen jäsentämisen välineitä, jotka auttavat tilannemääritelmien tekemisessä ja siten tilanteissa toimimisessa (ks. myös Kangas 2016, 212; Karvonen 2000, 79). Kehystämisessä on kyse valinnasta ja tärkeyden korostamisesta (Entman 1993, 52). Kehyksen sisältämä ennakkokäsitys todellisuuden rakentumisesta ohjaa siis journalistia korostamaan joitakin asioita ja jättämään vähemmän merkittävät huomiotta. Kehystäminen ei kuitenkaan ole vain valmiin raamin soveltamista, vaan se voi olla "luovaa maailman käsitteistämisen ja käsitettäväksi organisoimisen taidetta”. (Karvonen 2000, 82.)

Entmanin $(1993,52)$ mukaan kehystäminen on tiedostettua tai tiedostamatonta tiettyjen havaitun todellisuuden näkökulmien valintaa ja tärkeyden korostamista viestinnässä tavalla, joka tukee tiettyä ongelman määrittelyä, syy-seuraussuhteen tulkintaa, moraalista arviointia tai ratkaisuehdotusta kyseessä olevaan ongelmaan. Kehykset siis (1) määrittelevät, mitä jokin syy saa aikaan ja millä kustannuksella tai hyödyllä (ongelman määrittely), (2) identifioivat voimia, jotka luovat ongelman (syyn diagnosointi), (3) arvioivat syitä ja niiden seurauksia (moraalinen arviointi) ja (4) tarjoavat ja oikeuttavat ratkaisuehdotuksia ongelmiin sekä arvioivat niiden vaikutuksia (ratkaisuehdotusten tarjoaminen). Kehykset ilmenevät esityksessä esimerkiksi tiettyinä avainsanoina, vakiofraaseina, tietolähteinä ja kuvittamisen tapoina. (Emt., 52.)

Mediasisältöjen analysointi kehysten näkökulmasta on valintojen ja korostusten sekä poisjättämisen tutkimista (Kangas 2016, 213). Kuvista puhuttaessa ainakin kohteen ja kuvakulman valinta, rajaus ja editointi, julkaistavaksi päätyvien kuvien valinta sekä kuvan koon määrittely ja asemointi lehdessä ovat asioita, jotka vaikuttavat siihen, millaiset näkökulmat käsillä olevasta aiheesta korostuvat (Coleman 2010, 237; 
Schwalbe 2006, 269). Tässä tutkimuksessa keskitytään siihen, millaisia eettisen kuluttamisen näkökulmia valituilla kuva-aiheilla korostetaan. Lisäksi tarkastellaan kuvia ja niiden tekstiyhteyttä Entmanin $(1993,52)$ määritelmän sisältämän kausaalisuuden kautta. Eli tarkemmin sanottuna tarkastellaan, esittävätkö eettistä kuluttamista käsittelevien juttujen kuvat ongelmaa (esim. mikromuovi), sen syytä (esim. fleece-vaatteet) vai ongelmaan tarjottavaa ratkaisua (esim. mikromuovin keräävä pesupussi) ja miten vahvasti ongelman, syyn ja ratkaisun väliset yhteydet ilmaistaan.

\section{Aineisto ja metodi}

Tutkimuksen aineisto kerättiin systemaattisella otannalla vuoden 2017 Aamulehdistä helmi-, huhti-, kesä-, elo-, loka- ja joulukuulta (joka toinen kuukausi). Mukaan otettiin kyseisten kuukausien ensimmäiset täydet sekä kolmannet viikot. Lehden numeroita, joista juttuja etsittiin aineistoon, oli yhteensä 80 kappaletta. Tarkastelun ulkopuolelle jätettiin Aamulehden urheilu-, mielipide-, menot-, tehtävät- ja sarjakuvat-, radio\&televisio-, televisio- sekä tv-viikko-osiot. Aamulehden lisäksi mukaan kerättiin soveltuvat jutut lauantaisin ilmestyvästä Koti-liitteestä. Aineiston muodostavat tuotannon tai kulutuksen vaikutuksia ympäristölle yksilöiden/kuluttajien valintojen näkökulmasta käsittelevien juttujen kuvat sekä tarvittavin osin tekstit (kuvatekstit, otsikot, ingressit, leipätekstit, infolaatikot, nostot).

Valitsimme suomalaisista maakuntalehdistä näytteenomaisesti tutkimuskohteeksi Aamulehden. Tarkoituksenamme ei ole yleistettävän tiedon tuottaminen vaan ennemminkin yhden maakuntalehden eettistä kuluttamista koskevan sisällön ja erityisesti valokuvallisuuden kokonaisvaltainen tarkastelu. Vuosi 2017 oli tutkimuksen tekohetkellä tuorein mahdollinen tarkasteltava kalenterivuosi. Vuonna 2017 ilmastonmuutoskeskustelu myös aktivoitui voimakkaasti (Nikkanen 2017), mikä on voinut vaikuttaa siihen, että kuluttajanäkökulmaisia juttuja on julkaistu Aamulehdessä suhteellisen runsaasti. Laskennallisesti useammassa kuin joka toisessa lehden numerossa oli eettiseen kuluttamiseen liittyvä juttu. Aineistossa on 52 kuvaa ja ne on julkaistu osana 43 juttua.

Aineiston kerääminen oli haasteellista. Pelkkien kuvien ja kuvatekstien tai edes otsikon ja ingressin perusteella ei aina ollut mahdollista tunnistaa, tulisiko kuvat ottaa mukaan aineistoon vai ei. Asian varmentamiseksi jutut luettiin kokonaisuudessaan. Erityisen hankalaa oli ratkaista, olisiko jutun kuvat pitänyt ottaa aineistoon, jos juttu käsitteli kulutusvalintaa, jota tutkijan tietämyksen perusteella voitiin pitää eettisenä, mutta jota ei jutussa käsitelty lainkaan eettisyyden näkökulmasta.

Aineiston keruuta varten muotoiltiinkin seuraavat säännöt ja rajaukset: Eettisistä tuotteista kertovien juttujen kuvia ei otettu mukaan, jos tuotteen eettisyyttä ei tuotu jutussa esiin (esimerkki pois aineistosta jääneestä jutusta: Juupajoen kuukupeilla on jo miljoonia käyttäjiä, Aamulehti 22.10.2017). Pyöräilystä kertovien juttujen kuvat otettiin aineistoon, jos jutussa kerrottiin pyöräilyn vaikutuksista ympäristölle. Kasvisruokaa koskevien juttujen kuvat otettiin mukaan silloin kuin jutut käsittelivät ruokavaliota. Yksittäisestä kasviksesta kertovien juttujen tai ruokaohjeiden kuvia ei otettu mukaan, 
jos jutussa ei tuotu esiin eettistä näkökulmaa (esim. ilmastovaikutukset, hävikki). Ruokaa käsittelevien juttujen kuvat otettiin mukaan, jos juttujen otsikossa, ingressissä, kuvateksteissä tai nostoissa tuotiin esiin eettisiä tai ekologisia näkökulmia. Maininta luomusta tai lähiruoasta tulkittiin aina eettiseksi näkökulmaksi. Hyötyviljelystä kertovien juttujen kuvat otettiin aineistoon, vaikka on mainittava, että näissä jutuissa ei kovinkaan selkeästi tuotu esiin hyötyviljelyn eettisyyttä tai ekologisuutta.

Analysoimme Aamulehdessä julkaistujen eettisen kuluttamisen juttujen kuvien sisältöä määrällisen sisällönanalyysin keinoin. Sisällönanalyysi toimii kehysanalyysin pohjana eli sisällön luokittelun perusteella on mahdollista nähdä millaiset kuvasisällöt aineistossa korostuvat. Toisin sanoen mediakuvaston systemaattinen sisällönanalyysi auttaa löytämään vastauksia siihen, millaisia visuaalisia järjestyksiä eli visuaalisten esitysten säännönmukaisuuksia ja rakenteita eettisen kuluttamisen kuvallisessa julkisuudessa on löydettävissä (Seppänen 2001). Sisällönanalyysin muuttujien tarkoitus on siten kuvata tutkimuskysymyksen mukaisesti sitä, millaista eettisen kuluttamisen todellisuutta lehtikuvat rakentavat.

Sisällönanalyysissä käytetyt muuttujat perustuvat edellä esitettyyn eettisen kuluttamisen ja kuvilla kehystämisen tutkimuskirjallisuuteen, jonka pohjalta voidaan esittää päätutkimuskysymystä tarkentavia alakysymyksiä: Kuvastaako aineiston aihealueiden kirjo eettisen kuluttamisen monimutkaisuutta ja siihen kuuluvia moninaisia valintoja (esim. Moisander 2007; Pecoraro 2016)? Löytyykö aineistosta kuvastoa, joka linkittyy ihmisten arkeen ja kokemuksiin sekä huoleen omasta, perheen ja lähiympäristön hyvinvoinnista ja joka siten voisi mahdollisesti kannustaa lukijoita eettisiin valintoihin (Macnaghtenin 2003)? Millä tavalla kuvissa näkyvät tutkimuskirjallisuudessa esiin nousseet elämäntyyliliikkeet ja poliittinen osallistuminen (ns. arkipäivän aktivismi) (Haenfler ym. 2012; Craig 2016) tai vaihtoehtoinen hedonismi (Soper 2008)? Millainen on kytkös esitettyjen ongelmien ja niiden ratkaisujen välillä (Lorenzoni ym. 2006; O’Neill \& NicholsonCole 2009)? Aikaisemman vastaavan eettisen kuluttamisen visuaalisen esittämisen tutkimuksen puuttuessa muuttujien sisältöluokat on rakennettu edellä esitetyn kirjallisuuden ja aineiston tarjoaman sisällön perusteella.

\section{Ruokaa ja iloisia ihmisiä}

Tutkimuksen varsinainen aineisto koostuu kuvista $(n=52)$. Ensimmäiseen taulukkoon (ks. taulukko 1) on kuitenkin myös koodattu juttujen ( $n=43$ ) aihealueet. Se, millaisista aihealueista tai näkökulmista juttuja julkaistaan, vaikuttaa merkittävästi kuvaan, jota eettisestä kuluttamisesta journalistisilla jutuilla rakennetaan. Juttujen aihealueet luonnollisesti myös jossain määrin ohjaavat juttujen kuvien aiheita. On silmiinpistävää, miten voimakkaasti juttujen aihealueet painottuvat ruokaan: lähes 60 prosenttia jutuista käsittelee ruokaa. Mukana on luomuruokaa, ruokahävikkiä, tulevaisuuden ruokaa, vegaanista ruokaa, kasvisruokavaliota, hyötyviljelyä, lähiruokaa ja tilamyyntiä käsitteleviä juttuja. Myös ainoa ekologista siivousta käsittelevä juttu kertoo ruokaaineista, joita voi käyttää siivouksessa. Toiseksi eniten (14 \%) jutut käsittelevät autoja: 
autojen päästöjä, sähköautoja ja kaasuautoja. Ruoka- ja autojuttujen jälkeen kolmanneksi yleisin aihe on jätteet (9,3\%). Lisäksi aineistossa on yksittäisiä juttuja, joissa käsitellään energiaa, rakentamista, pyöräilyä, kierrätystä, suomalaisia vaatteita, ekologista siivousta ja (ei ruokaan liittyvää) ympäristöystävällistä tuotevaihtoehtoa.

Taulukko 1. Juttujen ensisijaiset aihealueet.

\begin{tabular}{|l|r|r|}
\hline Aihealue & $\mathbf{f}$ & $\mathbf{f}(\%)$ \\
\hline ruoka & 25 & 58,1 \\
\hline autot & 6 & 14 \\
\hline jätteet & 4 & 9,3 \\
\hline energia & 2 & 4,7 \\
\hline rakentaminen & 1 & 2,3 \\
\hline pyöräily & 1 & 2,3 \\
\hline kierrätys & 1 & 2,3 \\
\hline suomalaiset vaatteet & 1 & 2,3 \\
\hline ekologinen siivous & 1 & 2,3 \\
\hline ympäristöystävällinen tuotevaihtoehto & 1 & 2,3 \\
\hline Yhteensä & 43 & 100,0 \\
\hline
\end{tabular}

Varsinaisten kuva-aiheiden voidaan ajatella kertovan jotain siitä, miten lähelle inmistä eettinen kuluttaminen jutuissa pyritään tuomaan. Kuvavalinnoilla on esimerkiksi mahdollista ohjata mielikuvaa eettisestä kuluttamisesta ratkaisuna, joka joko edellyttää ihmisiltä aktiivisia toimia tai joka edellyttää lähinnä teknisiä edistysaskelia. Aineiston kuvat luokiteltiin kuva-aiheittain eli sen mukaan kuka tai mikä kuvassa on. Mikäli kuvassa oli keskeisessä roolissa ihminen tai ihmisiä, luokaksi koodattiin "ihminen/ihmisiä", vaikka kuvassa olisi ihmisten lisäksi myös jotain muuta, esimerkiksi teknologiaa tai luontoa.

Kuvastoa hallitsevat ihmiset, sillä yli puolessa $(55,8 \%)$ kuvista esiintyy ihminen tai inmisiä (ks. taulukko 2). Toiseksi eniten kuvissa (21,2 \%) on ruokaa tai ruokapakkauksia (mukana myös hyötykasveja, niiden taimia sekä yksi viljapelto) ja kolmanneksi eniten (11,5\%) teknologiaa (autoja, matkapuhelin, aurinkopaneeleihin liittyvää teknologiaa). Lisäksi kahdessa kuvassa on kotipuutarhurin kasvihuone, yhdessä kuvassa eläin (lehmä, joka kuvatekstin perusteella edustaa suomalaista naudanlihaa ja siten olisi voitu koodata myös ruokakategoriaan), yhdessä muovijätettä, ja yhdessä siivousaineeksi soveltuvia elintarvikkeita. Luontokategoriaan koodattiin vain yksi kuva, jossa on ruukkujoulukuusi. 
Taulukko 2. Kuka tai mikä kuvassa esiintyy?

\begin{tabular}{|l|r|r|}
\hline Kuva-aine & $\mathbf{f}$ & $\mathbf{f ~ ( \% )}$ \\
\hline ihminen/ihmisiä & 29 & 55,8 \\
\hline ruokaa tai ruokapakkaus & 11 & 21,2 \\
\hline teknologiaa & 6 & 11,5 \\
\hline kasvihuone & 2 & 3,8 \\
\hline eläin/eläimiä & 1 & 1,9 \\
\hline luontoa & 1 & 1,9 \\
\hline jätettä & 1 & 1,9 \\
\hline siivousaine & 1 & 1,9 \\
\hline Yhteensä & 52 & 100,0 \\
\hline
\end{tabular}

Kuvat, joissa esiintyy ihminen, luokiteltiin tarkempiin sisältöluokkiin kuvassa olevan keskeisen toimijan tai toimijoiden roolin mukaan. Tutkimuksen kannalta oleellista oli tunnistaa ainakin kuluttajan roolissa kuvissa esiintyvät inmiset. Muut muuttujan arvot on muodostettu aineiston perusteella. Yhdessäkään aineiston kuvista ei ole useissa eri rooleissa toimivia keskeisiä toimijoita (esim. samassa kuvassa kuluttaja ja kauppias), vaan mikäli kuvassa on useita toimijoita, he ovat kaikki samassa roolissa (esim. kolme keittiömestaria).

Kuvissa olevista ihmisistä yli puolet on kuluttajia (55,2 \%). Toiseksi suurimman ryhmän muodostavat ruokaan liittyvät ammattihenkilöt (34,3, \%). Näissä kuvissa esiintyy tutkijoita, suoramyyntitilan yrittäjä, ruokakauppias, pakkaaja, lihanleikkaaja, luomuviljelijä, kokkeja ja leipomotyöntekijä. Ruokaan liittyvien ammattihenkilöiden runsas esiintyminen tuntuu yllättävältä tulokselta, mutta toisaalta selittyy ruoka-aihealueen yleisyydellä aineistossa. Kuvastossa esitetään kuluttajien lisäksi ruoan kuluttamiseen liittyviä muita toimijoita. Tuottajien ja myyjien voimakas läsnäolo kuvissa vihjaa, että eettisessä kuluttamisessa on kyse ruoan ostamisesta. Kaiken kaikkiaan ihmiskuvien runsauden voidaan ajatella rakentavan eettisen kuluttamisen todellisuutta, jossa toimijoina ovat ihmiset.

Aikaisemmassa tutkimuksessa on ehdotettu, että perinteisen ympäristönsuojeluun liittyvän kuvaston lisäksi voisi olla mahdollista luoda toisenlaista sisältöä ja kuvastoa, joka linkittyisi paremmin ihmisten arkeen ja kokemuksiin ja siten aktivoisi ihmisiä toimimaan ympäristö huomioon ottaen (Macnaghten 2003, 79-80). Kuvissa näkyvä arkinen toiminta voisi siis auttaa ihmisiä näkemään eettinen kuluttaminen osana omaa toimintaansa. Kuvissa esitetty toiminta myös rakentaa käsitystä siitä, mistä eettisessä kuluttamisessa tarkemmin ottaen on kyse eli onko kyse vain ostamisesta vai myös muusta arkisesta toiminnasta, kuten korjaamisesta, siivoamisesta, kierrättämisestä tai jopa ostamatta jättämisestä.

Kuvat, joissa esiintyy ihminen, luokiteltiin sen mukaan, mitä ihminen tai ihmiset kuvassa tekevät. Hieman yllättäen kuvissa on toimintaa vain rajallisesti eikä arkisia toi- 
mia kuvaavia luokkia voitu muodostaa. Yli puolessa kuvista $(55,2 \%)$ ihmiset esittelevät tuotetta tai ratkaisua, jota jutussa käsitellään (ks. taulukko 3, kuvat 1 ja 2). Osassa kuvista ihminen konkreettisesti näyttää tuotetta käsissään lukijalle, toisissa tuote on kuvassa ja kuvateksti kertoo, että kuvan tarkoitus on esitellä jotain kuvassa olevaa. Lisäksi osassa kuvista (13,8 \%) ainoa havaittava toiminta on poseeraus. Vain kahdeksassa kuvassa (yht. 27,5\%) on aidontuntuista toimintaa. Kuluttajakuvissa maistetaan sirkkaleipää, poljetaan pyörällä ja kastellaan kasveja kasvihuoneessa. Puolessa aidon toiminnan kuvista toimija on joku muu kuin kuluttaja. Näissä kuvissa työskennellään: pakataan tuotteita, levitetään savilaastia ja asennetaan aurinkopaneeleja.

Taulukko 3. Mitä kuvassa tehdään?

\begin{tabular}{|l|r|r|}
\hline Toiminta & $\mathbf{f}$ & $\mathbf{f ~ ( \% ) ~}$ \\
\hline tuotteen/ratkaisun esittely & 16 & 55,2 \\
\hline työskentely & 5 & 17,2 \\
\hline poseeraus & 4 & 13,8 \\
\hline maistelu & 2 & 6,9 \\
\hline liikunta & 1 & 3,4 \\
\hline ei havaintoa & 1 & 3,4 \\
\hline Yhteensä & 29 & 100,0 \\
\hline
\end{tabular}

\section{Sirkkaleipä maistuu ihan tavalliselta}

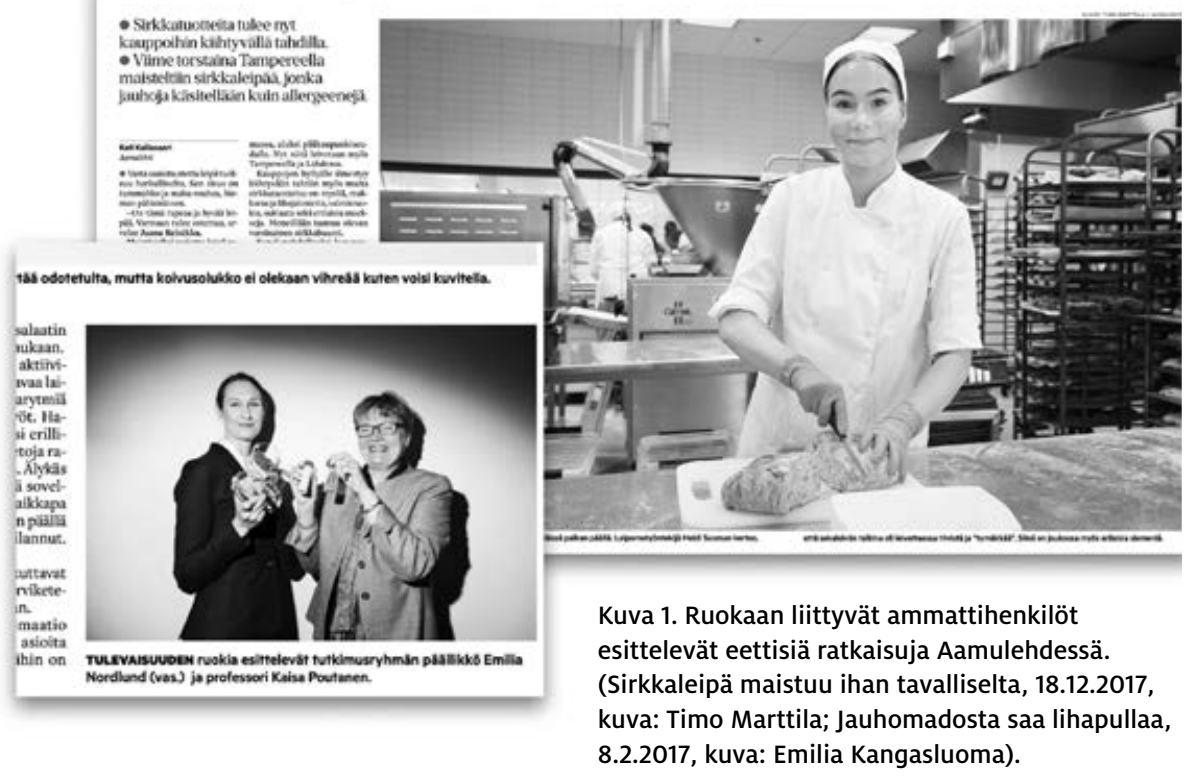




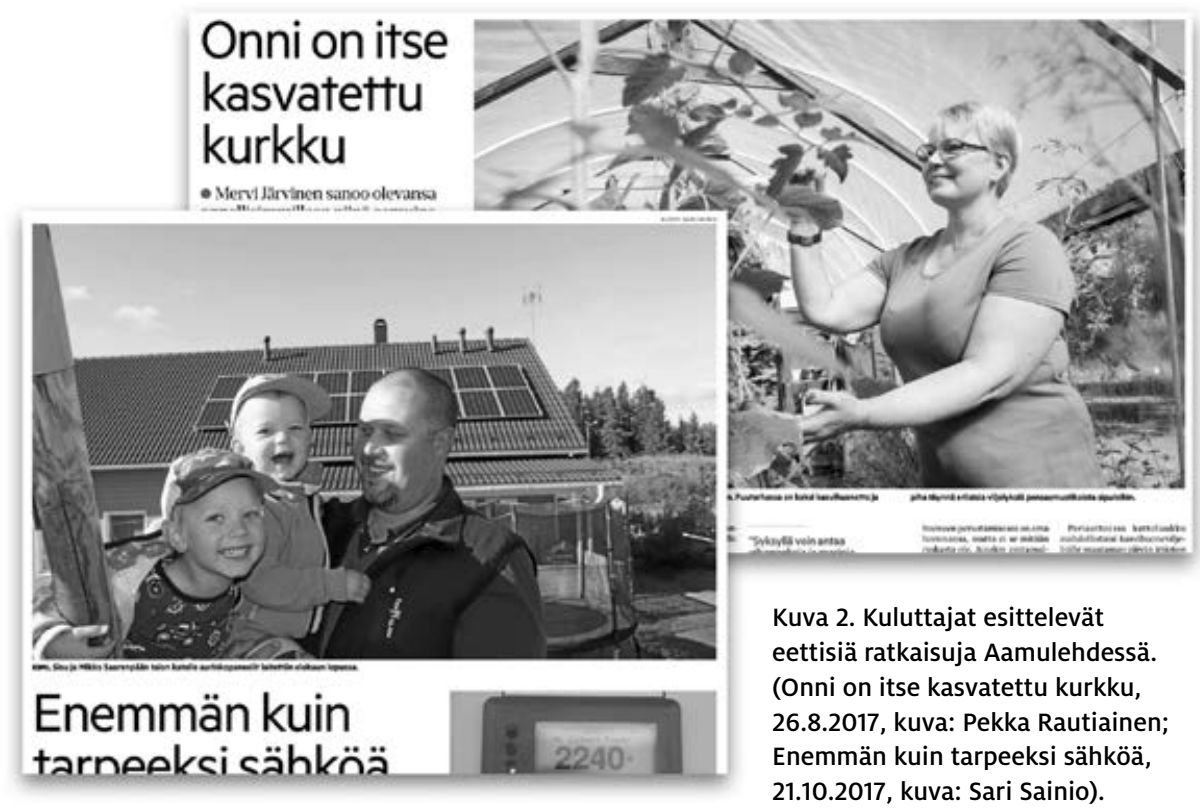

Mikäli eettisen kuluttamisen kuvaston toivotaan linkittyvän ihmisten arkeen, kuvassa esiintyvien ihmisten ja toiminnan lisäksi myös kuvauspaikka voi olla merkityksellinen. Eettisen kuluttamisen arkisina näyttämöinä kuluttajille toimivat ainakin kodin eri tilat sekä ostostentekopaikat. Toisaalta eettiseen kuluttamiseen liittyvät myös paikat, joissa kulutettavia hyödykkeitä tuotetaan.

Kuvista, joissa on ihmisiä, yhteensä noin neljäsosa (27,5 \%) on kuvattu kotiympäristössä (kotona, kotipihalla tai kodin rakennustyömaalla), mutta vain yksi näistä kuvista on varsinaisesti sisällä kuluttajan kodissa. Yhtä yleinen paikka $(27,6 \%)$ on jokin myymälä tai muu myyntitila. Edelleen lähes yhtä yleinen paikka $(24,1 \%)$ kuvissa on jokin tuotantotila kuten lihanleikkaamo, pakkaamo, ruokatehdas, ravintolan keittiö, koekeittiö ja leipomo.

Kun tarkastellaan paikka-muuttujaa pelkästään kuluttajien osalta, huomataan että useimmiten kuluttaja esitetään myymälässä tai muussa myyntitilassa (6 kuvaa). Tämä havainto vahvistaa mielikuvaa siitä, että eettinen kuluttaminen on ostamista. Toiseksi useimmiten kuluttaja esitetään kotipihalla (4 kuvaa). Vain yhdessä kuvassa kuluttaja on kuvattu sisällä omassa kodissaan. Eettinen kuluttaminen ei siis Aamulehden kuvissa esiinny asiana tai toimintana, joka tapahtuisi kodin seinien sisäpuolella.

Soperin (2008, 571-572) mukaan antikuluttamisen etiikan ja politiikan ei pitäisi vedota vain altruistiseen myötätuntoon ja ympäristöön liittyviin huoliin, vaan myös vaihtoehtoiseen hedonismiin eli eri tavalla kuluttamisen tuottamaan mielihyvään. Craign $(2016,125)$ tutkimuksen perusteella journalistisessa sisällössä kestävään elämäntapaan liittyvät nautinnot ovat kuitenkin vielä sivuosassa ja eettinen kuluttaja esitetään usein tiedollisesti puutteellisena, huolestuneena ja ahdistuneena. Olikin siis 
mielenkiintoista katsoa, millaisina kuluttajat tämän tutkimuksen kuva-aineistossa näyttäytyvät. Onko kuvissa nähtävissä toisin kuluttamiseen perustuvaa iloa vai pelkästään huolta ja ahdistusta. Tarkoitusta varten rakennettiin yksinkertainen muuttuja ja kuvista pyrittiin suurpiirteisesti arvioimaan siinä esiintyvän henkilön ilmeen perusteella, onko hän iloinen/tyytyväinen, surullinen/tyytymätön vai neutraali.

Tämän tutkimuksen aineiston kuvissa suurin osa ihmisistä on iloisia/tyytyväisiä (58,6 \%) tai neutraaleja (31,0 \%). Kukaan ihmisistä ei esiinny kuvissa surullisena/ tyytymättömänä. Tarkasteltaessa pelkkiä kuluttajia iloisuus tai tyytyväisyys jopa hieman korostuu, sillä tällöin lähes 70 prosenttia $(68,8 \%)$ kuluttajista esiintyy kuvissa iloisen/tyytyväisen oloisena. Vastoin aikaisempien tutkimusten havaintoja kuluttajia ei siis esitetä toimintansa ympäristövaikutuksista huolestuneina tai ahdistuneina kyvyttömyydestään toteuttaa kestävää elämäntapaa (ks. Craig 2016, 125). Toisaalta hyötyviljelystä kertovia juttuja lukuun ottamatta, kuvissa näkyvää iloisuutta on vaikea tulkita toisin kuluttamisen tuottamaksi nautinnoksi johtuen kuvissa esiintyvän toiminnan rajoittuneisuudesta. Ennemminkin iloiset ilmeet vaikuttavat liittyvän niissä nähtävään esittelyyn ja poseeraukseen.

Tässä luvussa esitetyn sisällönanalyysin perusteella voidaan sanoa, että Aamulehden eettisen kuluttamisen kuvia hallitsevat iloiset ihmiset ja ruoka. Kuvissa nähtävä toiminta on kuitenkin typistynyt esittelyyn, jolloin niissä on vain vähän aidon tuntuista, arkista toimintaa tai toisin kuluttamisen nautintoa. Ruokaan liittyvän ammattihenkilöstön runsas määrä kuvissa, esittely yleisimpänä toimintana, arkisen toiminnan puute ja se, ettei kuluttajia ole kuvattu omissa kodeissaan, luovat kaikki osaltaan kuvaa eettisestä kuluttamisesta ostamisena. Seuraavassa luvussa tarkastelemme aineiston kuvia Entmanin $(1993,52)$ kehyksen määritelmän sisältämän kausaalisuuden kautta eli tarkastelemme syitä, ongelmia ja ratkaisuja sekä niiden välisiä kytköksiä.

\section{Ongelmien ja ratkaisujen löyhät kytkökset}

Yksi tapa tarkastella kuvilla kehystämistä on pureutua siihen, miten kuvat ilmentävät tarkastelussa olevaa ongelmaa, sen syitä tai tarjolla olevia ratkaisumalleja (Kangas 2016, 213; Entman 1993, 52). Pelkkien kuvien ja kuvatekstien perusteella ei aineiston kuvista pystynyt aina päättelemään esittikö kuva ongelmaa, syytä vai ratkaisua, joten luokitellessa tukeuduttiin myös juttujen teksteihin kokonaisuudessaan.

Suurin osa $(86,5 \%)$ aineiston kuvista on niin sanottuja ratkaisukuvia. Vain kaksi kuvista (3,8 \%) kuvaa ongelmaa eli tuotannon tai kuluttamisen negatiivisia vaikutuksia ympäristölle, eikä mikään kuvista kuvaa ongelman syytä. Luokkaan "muu kuva" koodattiin henkilökuvat sekä kuvat, joita oli vaikea sijoittaa mihinkään luokkaan (5 kuvaa, 9,6\%). Huomionarvoista siis on, että vaikka ongelmakuvat kuuluvat olennaisesti ympäristönsuojelun ja ilmastonmuutoksen vakiintuneeseen kuvastoon (Macnaghten 2003, 65; Nikkanen 2017, 7), kuluttajanäkökulmaisista jutuista ne näyttävät puuttuvan lähes kokonaan. 
Tutkijat (Lorenzoni ym. 2006, 277; O’Neill \& Nicholson-Cole 2009, 376) ovat ehdottaneet, että ilmaston lämpenemisen paikallisia seurauksia (eli ongelmia) ja kansalaisille tarjoutuvia vaikutuskeinoja (eli ratkaisuja) yhdistävät mediarepresentaatiot voisivat olla toimiva poliittisen aktivoinnin keino. Kuvallisesti ongelmat ja ratkaisut eivät Aamulehden jutuissa tällä hetkellä yhdisty, sillä kuluttajanäkökulmaisissa jutuissa ongelmakuvia ei juuri käytetä ja silloin kun niitä käytetään, ne kuvittavat juttua yksin.

Ongelmien ja ratkaisujen kuvallisen yhteenliittämisen puuttuessa voidaankin tarkastella, tuodaanko jutun tekstissä esiin se, mihin ongelmaan kuvattua ratkaisua tarjotaan, kuinka helposti tuo kytkös on löydettävissä ja kuinka selkeästi se ilmaistaan. Vai jätetäänkö kuvan kytkös ongelmaan kenties epäsuoraksi vihjaukseksi tai jopa mainitsematta, jolloin yhteyden päättely jää kunkin lukijan henkilökohtaisen aiheentuntemuksen varaan (ks. myös Kangas 2016, 217)? Se, missä jutun osassa kytkös ilmaistaan, on myös visuaalinen kysymys. Juttua pintapuolisesti silmäilevän on helpompi havaita kytkös, jos se ilmaistaan esimerkiksi kuvatekstissä tai otsikossa, kuin jos se on piilotettu syvälle leipätekstiin.

Silmänliiketutkimusten perusteella tiedämme jonkin verran siitä, missä järjestyksessä lukijat etenevät sanomalehden sivulla (esim. Holmqvist \& Wartenberg 2005; Leckner 2012). Aikaisempaan tutkimukseen nojautuen olemmekin pyrkineet luomaan muuttujan, joka kuvaa miten helposti tai vaikeasti ratkaisun ja ongelman välinen kytkös on löydettävissä. Tässä tutkimuksessa kuvateksti on arvotettu ensimmäiseksi eli selkeimmäksi paikaksi ilmaista ongelma, johon ratkaisua kuvassa tarjotaan. Seuraavaksi selkeimmät tekstin osat ovat järjestyksessä otsikko, ingressi, nosto, infolaatikko, leipäteksti ja kainalojuttu. Ongelmien ja ratkaisujen yhteenliittämistä tarkastellessa aineistosta koodattiin jokaisen jutun ensimmäinen samaa ratkaisua kuvaava kuva ja siihen liittyvän ongelman kytkös.

Taulukossa 4 on esitetty se tekstin osa, jossa kytkös ensimmäisen kerran ilmaistaan. Se mihin ratkaisua tarjotaan, tuodaan pääosin esiin tekstissä $(40,7 \%)$ tai ingressissä (25,9\%). Ongelman ja ratkaisun välisen kytköksen löytämiseksi lukijan useassa tapauksessa oletetaan siis lukevan koko teksti. Yli viidennes $(22,2 \%)$ kuvista, jotka on luokiteltu ratkaisukuviksi, jää vaille selkeää sanallista kytkentää ongelmaan.

Taulukko 4. Tekstin osa, jossa ratkaisun ja ongelman välinen kytkös ilmaistaan.

\begin{tabular}{|l|r|r|}
\hline Tekstin osa & $\mathbf{f}$ & $\mathbf{f ~ ( \% )}$ \\
\hline teksti & 11 & 40,7 \\
\hline ingressi & 7 & 25,9 \\
\hline kuvateksti & 1 & 3,7 \\
\hline otsikko & 1 & 3,7 \\
\hline nosto & 1 & 3,7 \\
\hline ei selkeää mainintaa & 6 & 22,2 \\
\hline Yhteensä & 27 & $\mathbf{1 0 0 , 0}$ \\
\hline
\end{tabular}


Yli neljännessä osassa (25,9 \%) juttuja ongelma tuodaan esiin epäsuorasti käyttämällä jutussa ilmaisuja kuten ekologisuus, vastuullisuus, kuluttajan valveutuneisuus, ympäristösyyt jne. (ks. taulukko 5). Noin puolessa jutuista (51,9 \%) ongelmaa kuvataan tarkemmin, useimmiten tutkijoiden tai asiantuntijajärjestöjen äänellä, esimerkiksi:

WWF on arvioinut lihatuotteet neljän kriteerin perusteella. Ne ovat lihatuotannon vaikutukset ilmastolle, luonnon monimuotoisuudelle, vesistöjen rehevöitymiselle sekä torjunta-aineiden käyttö. (Tuontiliha joutui punaiselle listalle, Aamulehti 8.2.2017)

Yhdysvaltojen luomualaa edustavan Organic Trade Associationin johtaja Monique Marez sanoo, että tuoreiden tutkimustulosten mukaan luomumaataloudella on kiistattomia myönteisiä vaikutuksia ilmastonmuutokseen. (Luomumarkkina ylittää pian 300 miljoonaa euroa, Aamulehti 6.10.2017)

Perunan hiilijalanjälki on noin puolet pastaan eli vehnään tai kolmannes riisiin verrattuna. Peruna tarvitsee sekä vettä että pinta-alaa vähemmän kuin vehnä ja riisi. - Jussi Tuomisto, Johtaja, Perunantutkimuslaitos (Uudet perunat, Aamulehti 19.10.2017)

Taulukko 5. Ongelman muotoilu.

\begin{tabular}{|l|r|r|}
\hline Muotoilu & f & f (\%) \\
\hline tarkempi ongelma & 14 & 51,9 \\
\hline ratkaisun kuvailu ekologisena, vastuullisena jne. & 7 & 25,9 \\
\hline ei selkeää mainintaa & 6 & 22,2 \\
\hline Yhteensä & $\mathbf{2 7}$ & $\mathbf{1 0 0 , 0}$ \\
\hline
\end{tabular}

Noin puolessa jutuista ongelma ja ratkaisu siis yhdistyvät selkeästi tekstissä. Toisaalta toisessa puolikkaassa ongelman ja ratkaisun kytköstä ei ole tai se on epäsuora. Kuvien tekstiyhteydestä ilmenevä eettisen kuluttamisen (tai kulutuskulttuurin) yhteys ympäristöongelmiin, ilmastonmuutokseen tai muihin kulutuksen seurauksiin näyttäytyy suhteellisen löyhänä. Myös Kankaan $(2016,222)$ tutkimuksessa Helsingin Sanomien ilmasto-ongelman ratkaisukeinoja konkretisoivista kuvista jopa 36 prosentin verbaalinen ankkurointi oli löyhä tai olematon, jonka hän tulkitsi niin, että lukijan oletetaan mieltävän itsenäisesti kuvien sisältö ilmastonmuutoksen relevantiksi ratkaisukeinoksi. Samoin lukijan oletetaan tietävän mihin ympäristöongelmiin kuvissa esitettyjä eettisen kuluttamisen ratkaisuja hänelle tarjotaan. 


\section{Pohdinta}

Eettinen kuluttaminen on Aamulehdessä vuonna 2017 kehystetty kapeasti. Tämän tutkimuksen aineistossa ruoka on juttujen yleisin aihealue. Ruoka-aiheiset jutut käsittelevät mm. tulevaisuuden ruokaa, luomuruokaa, lähiruokaa, hyötyviljelyä ja kasvisruokavaliota. Vaikka ruoka on merkittävä hiilijalanjäljen osa-alue, juttujen aihealueiden perusteella muodostuva käsitys ruoasta eettisen kuluttamisen tärkeimpänä tai lähes ainoana osa-alueena ei ole yhtenevä hiilijalanjälkeä koskevan tutkimustiedon kanssa. Ruoan lisäksi suomalaisen kulutuksen hiilijalanjälkeen vaikuttavat asuminen, liikkuminen sekä ostetut tavarat ja palvelut. Ruoka ei ole Suomessa suurin hiilijalanjäljen osa-alue, vaan suurin yksittäinen kulutuksen hiilijalanjäljen osa-alue on asuminen. Suurin osa asumisen hiilijalanjäljestä taas syntyy lämmityksestä ja laitteiden sähkönkäytöstä. (Salo ym. 2016, 45-46.)

Aineistossa ei ole juttuja, joka käsittelisivät eettistä kuluttamista laaja-alaisesti. Toiseksi yleisin eettisen kuluttamisen aihe aineistossa on autot. Autoaiheiset jutut käsittelevät useimmiten sähköautoja. Yksityisautoilun nousu jutuissa eettisen kuluttamisen ratkaisuksi on jokseenkin ennalta-arvattavaa, sillä sähköautot ovat saaneet viime vuosina paljon ympäristömyönteistä medianäkyvyyttä. Sähköautojen ympäristöystävällisyys tai tehokkuus eettisen kuluttamisen ratkaisuna ei kuitenkaan ole yksiselitteistä, koska niiden kokonaispäästömäärä riippuu lataamiseen käytetyn sähkön tuotantotavasta sekä sähköautojen valmistukseen vaadittavasta energiamäärästä (EEA, 2017). Lisäksi kaikenlaisen yksityisautoilun vähentämistä pidetään tällä hetkellä välttämättömänä ilmastotavoitteiden saavuttamisessa (EASAC, 2019).

Aamulehden eettistä kuluttamista käsittelevien juttujen kuvia hallitsevat ihmiset. Toiseksi eniten kuvissa esiintyy ruokaa ja ruokapakkauksia. Suurin osa kuvien ihmisistä on kuluttajia. Kuluttajien lisäksi kuvissa esiintyy runsaasti ruokaan liittyviä ammattihenkilöitä. Kuvat siis rakentavat todellisuutta, jossa eettisen kuluttamisen keskeisimpiä toimijoita ovat yksittäiset kuluttajat ja ruoan myyntiin tai tuotantoon liittyvät henkilöt. Kankaan $(2016,216)$ tutkimuksessa ilmastonmuutoksen julkisista määrittelijöistä Helsingin Sanomien kuvissa selkeästi eniten näkyivät poliitikot, sitten kansalaiset, aktivistit ja tutkijat. Tämän tutkimuksen perusteella poliitikot tai aktivistit eivät toimijoina kuulu eettisen kuluttamisen kuvastoon. Aamulehden kuvissa ihmiset ovat yksilöinä kulutusvalintojen edessä. Kuluttaminen ei näyttäydy kuvissa poliittisena toimintana, esim. arkipäivän aktivismina (Conolly \& Prothero 2008, 140-141) tai osana ns. elämäntyyliliikkeitä (Haenfler ym. 2012, 2), jolloin niihin ei myöskään sisälly lupausta yhteistoiminnan voimasta.

Aineiston kuvissa esiintyvät kuluttajat ja ruokaan liittyvät ammattihenkilöt vaikuttavat iloisilta, tyytyväisiltä tai neutraaleilta. Tässä suhteessa tulokset poikkeavat aikaisemmasta tutkimuksesta (Craig 2016, 125), jonka mukaan eettinen kuluttaja esitetään usein huolestuneena ja ahdistuneena. Toisaalta tämän tutkimuksen aineiston kuvissa näkyvä toiminta on rajoittunutta. Kuvissa ihmiset useimmiten esittelevät jotakin tuotetta (tai ratkaisua) tai pelkästään poseeraavat, mikä osaltaan selittää kuvien iloisia ilmeitä. Hymy on vakiintunut ja voimakas valokuvassa poseeraamisen konventio (Kot- 
chemidova 2005). Arkista toimintaa tai ratkaistavia arjen tilanteita ei kuvissa ole juuri lainkaan, eikä siten myöskään toisin kuluttamisen nautintoa eli vaihtoehtoista hedonismia (Soper 2008, 571-572). Poikkeuksena tästä ovat hyötyviljelyä käsittelevät jutut, joissa kuvat hyötyviljelyä harrastavista naisista selkeästi kertovat itsekasvattamisen ilosta.

Suurin osa Aamulehden kuluttajanäkökulmaisten juttujen kuvista on odotetustikin niin sanottuja ratkaisukuvia, jotka esittävät eettisen ratkaisun johonkin ongelmaan. Noin puolessa jutuista kerrotaan suhteellisen selkeästi, mikä tämä ongelma on. Toisessa puolikkaassa ongelman ja ratkaisun yhteys on löyhä tai olematon, jolloin on lukijan omaamasta tietämyksestä kiinni, millä tavalla hän hahmottaa tarjotun ratkaisun liittyvän ympäristöongelmiin. Jutuissa ei myöskään vertailla erilaisia ratkaisuja ja niiden vaikutusmahdollisuutta tai tehokkuutta suhteessa kokonaisongelmaan. Tällainen kapea-alainen lähestyminen ja heikko kytkös suurempiin asiakysymyksiin on tuttua myös arkisesta eettisen kuluttamisen keskustelusta, joka usein päätyy yksittäisistä valinnoista tuskailuun (Lähde 2017). Kärjistäen voidaan sanoa, että aineiston perusteella eettisen kuluttajan tehtävä on lähinnä tehdä oikeanlaisia, yksittäisiä ruokaan liittyviä valintoja.

Kangas (2016) huomasi tutkiessaan ilmastonmuutoksen kuvastoa Helsingin Sanomissa, että ilmastojutuissa ei juuri tuotu esiin kansalaisten vaikutusmahdollisuuksia. Eli myös ongelmiin painottuneiden juttujen yhteys kansalaisille/kuluttajille mahdollisiin ratkaisuihin on löyhä. Vaikuttaakin siltä, että sekä ongelmia (laajempi näkökulma ympäristöongelmiin) että ratkaisuja (kuluttajanäkökulma ratkaisuihin) käsitteleviä juttuja on Aamulehdessä, mutta koska ne ovat erillisiä, niiden välinen yhteys voi jäädä lukijalta huomaamatta. Kuten tutkijat ovat ehdottaneet, näkökulmien tietoinen yhdistäminen voisi lisätä lukijoiden ymmärrystä omista vaikutusmahdollisuuksistaan (Lorenzoni ym. 2006, 277; O'Neill \& Nicholson-Cole 2009, 376). Eettisen kuluttamisen tarpeen perustelun haasteena voidaankin pitää syyn ja seurauksen ajallista ja paikallista erillisyyttä. Esimerkiksi naudanlihapihvin syöminen ei välittömästi nosta lämpötilaa tai vaatteen käyttäjä ei ole paikalla halpatuotantomaassa näkemässä kankaan värjäyksestä aiheutuvaa ympäristön saastumista. Samoin eettisen kuluttamisen hyödyt eivät välttämättä ole kuluttajalle heti nähtävissä. Ajallinen ja paikallinen erillisyys on haaste, joka journalistien tulisi kohdata.

Kaiken kaikkiaan huomionarvoista on Aamulehden juttujen keveys, ehkä jopa kaupallisuus ja löyhä yhteys ongelmiin. Monet jutut ja niiden kuvitukset rakentuvat jonkin tuotteen tai yrityksen ympärille. Kuvissa tuotteen tai ratkaisun esitteleminen on yleisin toiminta. Jos lähes kaikki jutut liittyvät ostovalintoihin, niin silloin eettinen kuluttaminen tulee määritellyksi nimenomaan ostamiseksi. Edellä esitetyn eettisen kuluttamisen kirjallisuuden mukaan eettinen kuluttaminen on kuitenkin moniulotteisempaa. Se voi olla eettisten ostopäätösten lisäksi esimerkiksi ei-ostamista eli boikotointia, kulutuksen minimointia ja kiertotalouteen siirtymistä.

Tämän tutkimuksen tulokset ovat linjassa ympäristötalouden ja johtamisen professori Lasse Linnasen väitteen "on tabu sanoa, että älä osta" kanssa. Hänen mukaansa ekologinen elämäntapa brändätään kalliiksi, vaikka todellisuudessa olisi kyse asioiden 
ostamatta jättämisestä (Thurén 2018). Ehkäpä "älä osta" sanomisen välttely on myös yksi syy siihen, miksi eettinen kuluttaminen esitetään nimenomaan ruokaan liittyvinä valintoina. Ravinto on perustarve, jonka ostamista ei juurikaan tarvitse perustella. Kuvaston ja juttujen painottuminen nimenomaan ruoan kuluttamiseen voi selittyä silläkin, että ruoan avulla voidaan helposti korostaa eettisen kulutuksen nautintoa ja hedonismia. Ruoka voi olla herkullista ja eettistä yhtä aikaa, ilman että mistään tarvitsee tinkiä.

IImeistä on, että lukijan ohjeistaminen energian ja luonnonvarojen kulutuksen sekä ympäristölle aiheutuvien haittojen vähentämiseen vaatii kuitenkin sanomaan "älä osta". Tutkija Ville Lähde (2017) listaa aiemmin mainittujen, suomalaisten hiilijalanjäljen muodostavien osa-alueiden (Salo ym. 2016) mukaisia peukalosääntöjä, joihin jokaiseen liittyy “älä osta” -aspekti:

Pitäisi asua pienemmissä, vähemmän lämmitetyissä asunnoissa, joiden energiaa ei ole tuotettu fossiilisilla polttoaineilla. Tulisi liikkua mahdollisimman paljon julkisilla liikennevälineillä, pyöräillen tai jalan. Ruokavalion olisi koostuttava mahdollisimman paljon kasvikunnan tuotteista. Jos nämä asiat eivät ole kunnossa, kaikki muu on toissijaista.

"Älä osta" ei ehkä sanota myöskään siksi, että kuluttajien vastuuttamisen ajatellaan olevan epäreilua (esim. Moisander 2007). Kuitenkin poliittisten päätösten ja rakenteellisten muutosten lisäksi myös kulutuspäätöksillä on merkitystä ja nykyistä kestävämmät kulutusvalinnat ovat välttämätön osa ympäristöongelmien ratkaisua (Claudelin ym. 2018). Vastuuttamisen sijaan eettistä kuluttamista voidaankin lähestyä myös oikeuksien näkökulmasta: jokaisella on oikeus ja mahdollisuus vaikuttaa omilla valinnoillaan.

Tällä tutkimuksella on kartoitettu eettisen kuluttamisen esittämistä journalismissa yhden merkittävän suomalaisen paikallismedian osalta. Vaikka tulokset eivät ole laajasti yleistettävissä, ne kertovat jotain oleellista siitä, millaista eettisen kuluttamisen todellisuutta suomalaiset lehtikuvat tällä hetkellä rakentavat. Tutkimuksen tuloksia arvioidessa oli tärkeää ottaa huomioon jutuissa käsiteltyjen eettisen kuluttamisen aihealueiden lisäksi ne aihealueet, joita jutuissa ei käsitelty, sillä aineiston kuvien kautta rakentuva todellisuus on kapea-alainen. Uskomme, että tutkimuksemme tulokset avaavat tietä jatkotutkimuksille, joissa laajemman sisällön tarkastelun lisäksi voidaan myös keskittyä journalististen työprosessien tutkimiseen ja kehittämiseen.

Kuten tämän artikkelin teoreettisessa osuudessa esitelty kirjallisuus osoitti, eettinen kuluttaminen on monimutkainen ilmiö. Journalistisissa esityksissä voidaan siis tarvita konkretisointia ja yksinkertaistamista. Eettisen kuluttamisen liiallinen yksinkertaistaminen kuitenkin vääristää kuvaa kuluttajien vaikutusmahdollisuuksista. Tärkeää olisikin löytää tasapaino monipuolisuuden ja yksinkertaistamisen väliltä. Yksinkertaistamisen avuksi voitaisiin ottaa esimerkiksi saatavilla oleva tieto siitä, mistä kuluttajien hiilijalanjälki muodostuu.

Tämän tutkimuksen aineiston kuvista emme juurikaan löytäneet piirteitä, joita aikaisemman tutkimuksen perusteella olisi voitu pitää kestävään elämäntyyliin kan- 
nustavina tai sitouttavina. Kuvastoa hallitsivat iloiset inmiset, jolloin eettisen kuluttamisen voidaan ajatella kytkeytyvän myönteisiin tunnetiloihin. Kuvissa oli kuitenkin hyvin rajoitetusti toimintaa eikä iloisuus vaikuttanut suoraan liittyvän toisin kuluttamisen nautintoon (Soper 2008). Kosketuspintaa arkisiin kokemuksiin oli vain vähän. Lisäksi kytkökset eettisten ratkaisujen ja ympäristöongelmien välillä olivat löyhiä. Meillä on selkeä tarve tutkimukselle, joka keskittyy selvittämään, millaiset mediaesitykset ja -kuvat voisivat herätellä inmisten ympäristötoimijuutta ja edesauttaa sitoutumista kestävään arkeen. Tällainen tutkimus voisi omalta osaltaan raivata tietä myös journalismille, joka käsittelee eettisen kuluttamisen teemoja nykyistä laajemmin ja syvällisemmin.

\section{Viitteet}

Artikkelissa hyödynnetty aineisto on kerätty osana ensimmäisen kirjoittajan Pro gradu -tutkielmaa (Niemelä-Nyrhinen 2018).

\section{Aineistoviitteet}

Aamulehti (8.2.2017). Riikka Happonen (teksti): Tuontiliha joutui punaiselle listalle.

Aamulehti (6.10.2017). Kaisa Hahto (teksti): Luomumarkkina ylittää pian 300 miljoonaa euroa.

Aamulehti (19.10.2017). Elina Pajunen (teksti): Uudet perunat.

Aamulehti (18.12.2017). Timo Marttila (kuva): Sirkkaleipä maistuu ihan tavalliselta.

Aamulehti (8.2.2017). Emilia Kangasluoma (kuva): Jauhomadosta saa lihapullaa.

Aamulehti (26.8.2017). Pekka Rautiainen (kuva): Onni on itse kasvatettu kurkku.

Aamulehti (21.10.2017). Sari Sainio (kuva): Enemmän kuin tarpeeksi sähköä.

\section{Kirjallisuus}

Ahva, Laura (2010). Making news with citizens: public journalism and professional reflexivity in Finnish newspapers (väitöskirja). Tampere: University Press.

Anderson, Alison (1997). Media, Culture and the Environment. London: UCL Press.

Carrigan, Marylyn; Szmigin, Isabelle \& Wright, Joanne (2004). Shopping for a better world? An interpretive study of the potential for ethical consumption within the older market. Journal of Consumer Marketing 21:6, 401-417. https://doi.org/10.1108/07363760410558672

Cherrier, Hélène (2006). Consumer Identity and Moral Obligations in Non-Plastic Bag Consumption: A Dialectical Perspective. International Journal of Consumer Studies 30:5, 515-523.

Cherrier, Hélène (2009). Anti-consumption discourses and consumer-resistant identities. Journal of Business Research 62:2, 181-190. https://doi.org/10.1111/j.1470-6431.2006.00531.X

Cherrier, Hélène \& Murray, Jeff (2002). Drifting away from excessive consumption: A new social movement based on identity construction. Advances in Consumer Research 29:1, 245-247. https://doi. org/10.1016/j.jbusres.2008.01.025

Claudelin, Anna; Järvelä, Sini; Uusitalo, Ville; Leino, Maija \& Linnanen, Lassi (2018). The Economic Potential to Support Sustainability through Household Consumption Choices. Sustainability 10:11, 3961. https://doi.org/10.339o/su10113961

Cohen, Stanley (2001). States of Denial. Knowing about Atrocities and Suffering. London: Polity.

Coleman, Renita (2010). Framing the pictures in our heads: Exploring the framing and agenda-setting effects of visual images. Teoksessa: D’Angelo, Paul \& Kuypers, Jim A. (toim.). Doing News Framing Analysis. Empirical and Theoretical Perspectives. New York: Routledge, 233-261. 
Conolly, John \& Prothero, Andrea (2003). Sustainable consumption: Consumption, consumers and the commodity discourse. Consumption, Markets Q Culture 6:4, 275-291.

Conolly, John \& Prothero, Andrea (2008). Green consumption: Life-politics, risk and contradictions. Journal of Consumer Culture 8:1, 117-145.https://doi.org/10.1080/1025386032000168311

Craig, Geoffrey (2016). Political participation and pleasure in green lifestyle journalism. Environmental Communication 10:1, 122-141. https://doi.org/10.1080/17524032.2014.991412

EASAC (2019). Decarbonisation of Transport: options and challenges. Policy Report 37. Saatavilla: https:// easac.eu/publications/details/decarbonisation-of-transport-options-and-challenges/ (luettu 20.6.2019).

EEA (2017). Range of life-cycle $\mathrm{CO}_{2}$ emissions for different vehicle and fuel types. Saatavilla: https://www. eea.europa.eu/signals/signals-2017/infographics/range-of-life-cycle-c02/view (luettu 20.6.2019).

Eide, Martin \& Knight, Graham (1999). Public/private service: Service journalism and the problems of everyday life. European Journal of Communication 14:4, 525-547. https://doi. org/10.1177/0267323199014004004

Entman, Robert (1993). Framing: Towards clarification of a fractured paradigm. Journal of Communication 43:4, 51-58. https://doi.org/10.1111/j.146o-2466.1993.tbo1304.x

Fields Milburn, Joshua \& Nicodemus, Ryan (2014). Imagine Everything. Saatavilla: https://www. theminimalists.com/imagine-everything/ (luettu 15.3.2019).

Figueres, Christiana; Schellnhuber, Hans Joachim; Whiteman, Gail; Rockström, Johan; Hobley, Anthony \& Rahmstorf, Stefan (2017). Three years to safeguard our climate. Nature 546:766o, 593-595. https:// doi.org/10.1038/546593a

Goffman, Erving (1986). Frame Analysis. An Essay on the Organization of Experience. Boston: Northeastern University Press.

Goodman, Michael; Littler, Jo; Brockington, Dan \& Boykoff, Maxwell (2016). Spectacular environmentalisms: Media, knowledge and the framing of ecological politics. Environmental Communication 10:6, 677-688. https://doi.org/10.1080/17524032.2016.1219489

Haenfler, Ross; Johnson, Brett \& Jones, Ellis (2012). Lifestyle movements: Exploring the intersection of lifestyle and social movements. Social Movements Studies 11:1, 1-20. https://doi.org/10.1080/147428 37.2012.640535

Hannigan, John (2006). Environmental Sociology. London \& New York: Routledge.

Hanusch, Folker (2012). Broadening the focus: The case of lifestyle journalism as a field of scholarly inquiry. Journalism Practice 6:1, 2-11. https://doi.org/10.1080/17512786.2011.622895 https://doi.org/10.1177/1461445608098200

Heikkilä, Heikki; Ahva, Laura; Siljamäki, Jaana \& Valtonen, Sanna (2012). Kelluva kiinnostavuus. Tampere: Vastapaino.

Heller, Agnes (1988) General Ethics. Oxford: Basil Blackwell.

Holmqvist, Kenneth \& Wartenberg, Constanze (2005). The Role of Local Design Factors for Newspaper Reading Behaviour: An Eye-tracking Perspective, 127. Lund: Lund University Cognitive Studies. Saatavilla: http://www.lucs.lu.se/LUCS/127/LUCS.127.pdf (luettu 25.6.2019).

Howarth, Anita (2012). Participatory politics, environmental journalism and newspaper campaigns. Journalism Studies 13:2, 210-225. https://doi.org/10.1080/1461670x.2011.646398

Kangas, Jarkko (2016). Näkymätön ilmasto, näkyviä kuvia: Ilmastoriskin visualisointi ja kuvallinen kehystäminen. Media Q viestintä 39:4, 209-227. https://doi.org/10.23983/mv.61407

Karvonen, Erkki (2000). Tulkintakehys (frame) ja kehystäminen. Tiedotustutkimus 23:2, 78-84.

Kotchemidova, Christina (2005). Why we say "cheese": Producing the smile in snapshot photography. Critical Studies in Media Communication 22:1, 2-25. https://doi.org/10.1080/0739318042000331853

Leckner, Sara (2012). Presentation factors affecting reading behaviour in readers of newspaper media: an eye-tracking perspective. Visual Communication 11:2, 163-184. https://doi. org/10.1177/1470357211434029

Lorenzoni, Irene; Leiserowitz, Anthony; De Franca Doria, Miguel; Poortinga, Wouter \& Pidgeon, Nick (2006). Cross-national comparisons of image associations with "global warming" and "climate change" among laypeople in the United States of America and Great Britain. Journal of Risk Research 9:3, 265-281. https://doi.org/10.1080/13669870600613658

Lähde, Ville (2017). Älä eksy silpputiedon viidakkoon. Huili. Saatavilla: http://www.huililehti.fi/ala-eksysilpputiedon-viidakkoon/ (luettu 1.6.2018). 
Macnaghten, Phil (2003). Embodying the environment in everyday life practices. The Sociological Review 51:1, 63-84. https://doi.org/10.1111/1467-954x.00408

Moisander, Johanna (2007). Motivational complexity of Green Consumerism. International Journal of Consumer Studies 31:4, 404-409. https://doi.org/10.1111/j.1470-6431.2007.00586.x

Niemelä-Nyrhinen, Jenni (2018). Eettinen kuluttaminen lehtikuvissa. Pro gradu -tutkielma, Tampereen yliopisto. http://urn.fi/URN:NBN:fi:uta-201809062471

Nikkanen, Hanna (2017). Uutisista suurin. Teoksessa: Työryhmä \& Nikkanen, Hanna (toim.). Hyvän sään aikana: Mitä Suomi tekee, kun ilmasto muuttaa kaiken? Helsinki: Into, 7-10.

O’Neill, Saffron \& Nicholson-Cole, Sophie (2009). "Fear won't do it": Promoting positive engagement with climate change through visual and iconic representations. Science Communication 30:3, 355-379. https://doi.org/10.1177/1075547008329201

Pecoraro, Maria (2016). Eettinen kuluttaminen kulutuskulttuurissa (väitöskirja). Jyväskylä: University of Jyväskylä. Jyväskylä Studies in Business and Economics 171.

Penaloza, Lisa \& Price, Linda (1993). Consumer resistance: A conceptual overview. Advances in Consumer Research 20:1, 123-128.

Pietilä, Veikko (1997). Joukkoviestintätutkimuksen valtateillä. Tampere: Vastapaino.

Pihkala, Panu (2017). Päin helvettiä? Ympäristöahdistus ja toivo. Helsinki: Kirjapaja.

Salo, Marja; Nissinen, Ari; Mäenpää, Ilmo \& Heikkinen, Mari (2016). Kulutuksen hiilijalanjäljen seurantaa tarvitaan. TietoQTrendit - Talous- ja hyvinvointikatsaus 1, 44-50.

Schwalbe, Carol (2006). Remembering our shared past: Visually framing the Iraq war on U.S. news websites. Journal of Computer-Mediated Communication 12:1, 264-289. https://doi.org/10.1111/j.10836101.2006.00325.x

Seppänen, Janne (2001). Katseen voima - kohti visuaalista lukutaitoa. Tampere: Vastapaino.

Szmigin, Isabelle; Carrigan, Marylyn \& McEachern, Morven (2009). The conscious consumer: taking a flexible approach to ethical behaviour. International Journal of Consumer Studies 33:2, 224-231. https://doi.org/10.1111/j.1470-6431.2009.00750.x

Soper, Kate (2008). Alternative hedonism, cultural theory and the role of aesthetic revisioning. Cultural Studies 22:5, 567-587. https://doi.org/10.1080/09502380802245829

Thurén, Julia (2018). Avaaja Lassi Linnanen: "On tabu sanoa, että älä osta." Image. Saatavilla: https://www. apu.fi/artikkelit/avaaja-lassi-linnanen-on-tabu-sanoa-etta-ala-osta (luettu 2.5.2018).

Özçaglar-Toulouse, Nil; Shiu, Edward \& Shaw, Deidre (2006). In search of fair trade: ethical consumer decision making in France. International Journal of Consumer Studies 30:5, 502-514. https://doi. org/10.1111/j.1470-6431.2006.00532.x 